\title{
The impact of lamb cleanliness and line speed on the effectiveness of steam vacuum and carcass wash as decontamination methods after slaughter by da Silva, S. and Farag, K.
}

Copyright, publisher and additional Information: This is the author accepted manuscript. The final published version (version of record) is available online via Elsevier.

This version is made available under the CC-BY-ND-NC licence

Please refer to any applicable terms of use of the publisher

DOI link to the version of record on the publisher's website

$\mathbf{H}$

Harper Adams University 


\title{
The impact of lamb cleanliness and line speed on the effectiveness of steam vacuum and carcass wash as decontamination methods after slaughter
}

\begin{abstract}
This study assessed the effectiveness of steam vacuum and carcass wash in decontaminating lamb carcasses by measuring Enterobacteriaceae, total viable counts (TVC), and visible contamination. In addition, different levels of fleece cleanliness and different line speeds were evaluated for each group. The sampling covered four groups: i) control, ii) steam vacuum, iii) carcass wash, and iv) steam vacuum and carcass wash.

A total of 660 surface swabs were collected: i) before treatment, ii) after treatment, and iii) 24 hours post chilling. The results showed that Enterobacteriaceae and TVC means were significantly lower $(P<0.001)$ on the steam vacuum group compared to the other groups, both after treatment and after chilling. Conversely, the carcass wash was effective in removing visible contamination but not significant on microbial reduction. There was a significant difference $(P<0.001)$ between line speeds on TVC means, but not on Enterobacteriaceae means. Cat 3 unshorn lambs yielded carcasses with the lowest Enterobacteriaceae means, but with greatest TVC means and wool contamination.
\end{abstract}

\section{Keywords}

Lamb carcass; Steam vacuum; Carcass wash; Decontamination 


\section{Introduction}

Meat consumption has increased throughout the years, driven by population growth, rising individual incomes, and changes on consumer demand for higher protein intake (Godfray et al., 2018). The increase and globalisation of the meat trade promoted transformation in meat production systems and extended food supply chains. The complexity of meat supply chains has led to important implications for public health, as contaminated meat can rapidly result in geographically widespread foodborne outbreaks (Behravesh et al., 2012).

For this reason, regulatory authorities alongside the meat industry strive to control and reduce the presence of pathogens in meat with the implementation of preventative food safety systems, such as Hazard Analysis and Critical Control Points (HACCP), in slaughterhouses and meat cutting plants (Milios et al., 2017). Even though the HACCP foundation is comprised of strict good hygienic practices employed during slaughter and processing, there is a growing interest in intervention methods and treatments, pre and post slaughter, as total prevention of microbial contamination during slaughter can hardly be guaranteed (Hochreutener et al., 2017).

The sheep fleece is recognised as the primary vehicle for the introduction of contamination to the slaughter line due to accumulated dust, dirt, and faecal matter. Therefore, clean fleece is a prerequisite for production of safe meat (Fisher et al., 2007). Based on this criterion, several countries have established systems to assess and improve the cleanliness of sheep destined for slaughter (Hauge et al., 2011).

In the United Kingdom (UK), a 'clean livestock policy' has been established by the Meat Hygiene Service (MHS). This policy consists of a visual assessment of fleece cleanliness, regarding presence of soiling and wetness, of animals presented for slaughter and allocating a score from one to five accordingly (FSA, 2007). Based on the selected category, control measures such as retaining these animals in lairage to dry and slaughter at the end of the day, shearing before or immediately after slaughter, and reduced line speed, may be implemented to prevent carcass contamination during slaughter and dressing operations (FSA, 2002).

Shearing usually improves the visual cleanliness of the fleece since soil and faeces are mostly present in the outer layer, whilst the interior of the fleece is clean (Hauge et al., 2011). Shearing before slaughter has been linked with reduction of microbial load and spoilage bacteria on carcass surface (Biss and Hathaway, 1996; Omer et al., 2015) Also, the Hauge et al. (2011) study has revealed a significant reduction on aerobic plate count on carcasses from sheep shorn immediately before slaughter, but no substantial reduction on $E$. coli levels. 
Additionally, post slaughter intervention methods have been developed and proven to be effective in reducing contamination on carcasses (Hugas and Tsigarida, 2008). Washing carcasses with water is an intervention method commonly used in abattoirs with the aim of removing visible contamination such as soil, bone dust, blood cloths, and other debris (Bolton et al., 2001; Dickson and Acuff, 2017). Nevertheless, several studies have evaluated the ability of carcass washes as intervention methods to reduce bacterial contamination (Milios et al., 2017). Research on carcasses washed with water at ambient temperature has shown microbial reduction (Dorsa et al., 1996). Whilst, other studies with cold and warm water have shown no reduction in microbial contamination (Gill et al., 1996; Bell, 1997). Conversely, studies have also shown the effectiveness of hot water $\left(>74^{\circ} \mathrm{C}\right)$ to reduce microbial contamination on beef and lamb carcasses (Huffman, 2002).

An alternative treatment to hot water is the application of steam. The carcass steam vacuum is a hand-held device which uses steam and vacuum to decontaminate targeted areas on the carcasses. This intervention method has been approved in USA as a substitute to knife trimming for the removal of faecal and ingesta contamination when these contaminants have an area no greater than $2.54 \mathrm{~cm}^{2}$ (Huffman, 2002).

Some studies have been conducted on the effectiveness of the steam vacuum since its introduction in commercial abattoirs in the early 1990s (Dorsa et al., 1996; Kochevar et al., 1997; Bacon et al., 2002). However, only a few were performed in commercial environments with naturally contaminated carcasses (Hochreutener et al., 2017). The majority of studies were employed on beef carcasses and the few studies conducted on sheep and lamb carcasses (Milios et al., 2011; Hassan et al., 2015; Omer et al., 2015) did not employ a fleece cleanliness categorisation. Also, the line speed applied during these studies was not identified (Milios et al., 2011) or was relatively slow (Hassan et al., 2015; Omer et al., 2015) when compared to the abattoir in this study.

The objective of this research was to evaluate the effectiveness of steam vacuum and carcass wash in decontaminating lamb carcasses when employed in a commercial environment, on carcasses from different fleece cleanliness categories, and on different slaughter line speeds. 


\section{Materials and methods}

\subsection{Abattoir and slaughter process}

This study was conducted during the period of April and May in an authorised commercial abattoir located in the UK. The facility has total annual sheep slaughter capacity of over 900,000. The plant has implemented a HACCP plan and is certified according to British Retail Consortium (BRC v8) standard.

The slaughter line was operated by professional personnel who employed a two-knifemethod. Fleece removal started by a mid-line cut through the breast and belly, and cuts along each front leg and throat, whilst the carcass was suspended by the fore and hind legs. The fleece was then manually detached from the forelegs, shoulders, and breast following the automatic head removal. After this the semi-automatic rodding of oesophagus was performed using a rubber band. Located immediately after this point was the steam vacuum equipment. The fleece was then completely removed by an automatic downward puller whilst the carcass was suspended by the forelegs.

The carcass was then inverted to be suspended by hind legs, the circum-anal incision was performed, and the intestines were removed. Following the pluck removal and quality control points, the carcass was presented to Meat Hygiene Inspectors for post-mortem inspection. Immediately after grading the carcass entered a High Voltage Electrical Stimulation (HVES) cabinet, which was followed by a chilling regime of 3 hours and then stored at $0^{\circ} \mathrm{C}$ for 24 hours. The carcasses were hung on single-hooks which allowed their surfaces to dry and chill quickly.

\subsection{Samples collection}

A total number of 240 carcasses $(n=660)$ were selected at the beginning of the slaughter line, immediately after kill for inclusion in this study. Sampling was conducted throughout the course of six weeks during nine working days. All carcasses were derived from sheep under 12 months of age.

Forty carcasses from each selected cleanliness category were divided into four groups, each of 10 carcasses, which were treated as follows and as described in Table 1: i) no decontamination treatment, ii) steam vacuum, iii) carcass wash, and iv) steam vacuum and carcass wash. The carcasses were swabbed immediately before and after the treatment application, and 24 hours after the chilling regime. 
Two different slaughter line speeds (approximately 410 and 500 carcasses per hour) were employed during this study, to capture the most commonly employed line speeds.

The sampling site selected was as shown in Figure 1. Milios et al. (2014) advocated that a large number of aerobic bacteria have been observed mainly on the shoulder area. Furthermore, the foreleg, elbow, and external aspect have been identified as sites often highly contaminated in lamb carcasses (ISO, 2015). The swabbing area was approximately $580 \mathrm{~cm}^{2}$ alternating from the left and right side of the carcass (i.e. before treatment on left side, after treatment on the right side, after chilling regime again on left side, or vice versa).

Table 1 Type and number of samples collected.

\begin{tabular}{|l|c|c|c|c|c|c|c|}
\hline \multicolumn{1}{|c|}{$\begin{array}{c}\text { Carcass cleanliness } \\
\text { category (n) }\end{array}$} & $\begin{array}{c}\text { Line } \\
\text { speed } \\
\text { Carcasses } \\
\text { per hour }\end{array}$ & $\begin{array}{c}\text { No } \\
\text { treatment } \\
\text { (Control) }\end{array}$ & $\begin{array}{c}\text { Steam } \\
\text { vacuum }\end{array}$ & $\begin{array}{c}\text { Carcass } \\
\text { wash } \\
\text { vacuum } \\
\text { +carcass } \\
\text { wash }\end{array}$ & $\begin{array}{c}\text { After } \\
24 \mathrm{~h} \\
\text { chilling }\end{array}$ & $\begin{array}{c}\text { Total } \\
\text { number } \\
\text { of } \\
\text { samples }\end{array}$ \\
\hline Category 2 (40) & 410 & 10 & 20 & 20 & 20 & 40 & 110 \\
\hline Category 2 (40) & 500 & 10 & 20 & 20 & 20 & 40 & 110 \\
\hline Category 3- shorn (40) & 410 & 10 & 20 & 20 & 20 & 40 & 110 \\
\hline Category 3- shorn (40) & 500 & 10 & 20 & 20 & 20 & 40 & 110 \\
\hline Category 3- unshorn (40) & 410 & 10 & 20 & 20 & 20 & 40 & 110 \\
\hline Category 3- unshorn (40) & 500 & 10 & 20 & 20 & 20 & 40 & 110 \\
\hline Total (240) & & 60 & 120 & 120 & 120 & 240 & 660 \\
\hline
\end{tabular}

\subsection{Cleanliness categorisation}

The visual assessment of the fleece cleanliness was conducted at intake in the lairage by the abattoir operatives. Lambs were categorised as per MHS Clean Livestock Policy, as shown in Table 2. The 'clean livestock policy' was already employed by the abattoir and all lairage operatives were trained on this method. Moreover, the categorisation assigned to each lot was verified by the Official Veterinarian conducting the ante-mortem inspection on site, before the animals were presented to slaughter.

In this study only categories two (Cat 2) and three (Cat 3S (shorn) and Cat 3U (unshorn)) were utilised due to the lack of availability of categories one and four at the time of year the study was carried out. Nevertheless, categories two and three are also the most predominant all year round. Also, where fleece clipping was required this was conducted on the slaughter line immediately after kill. 


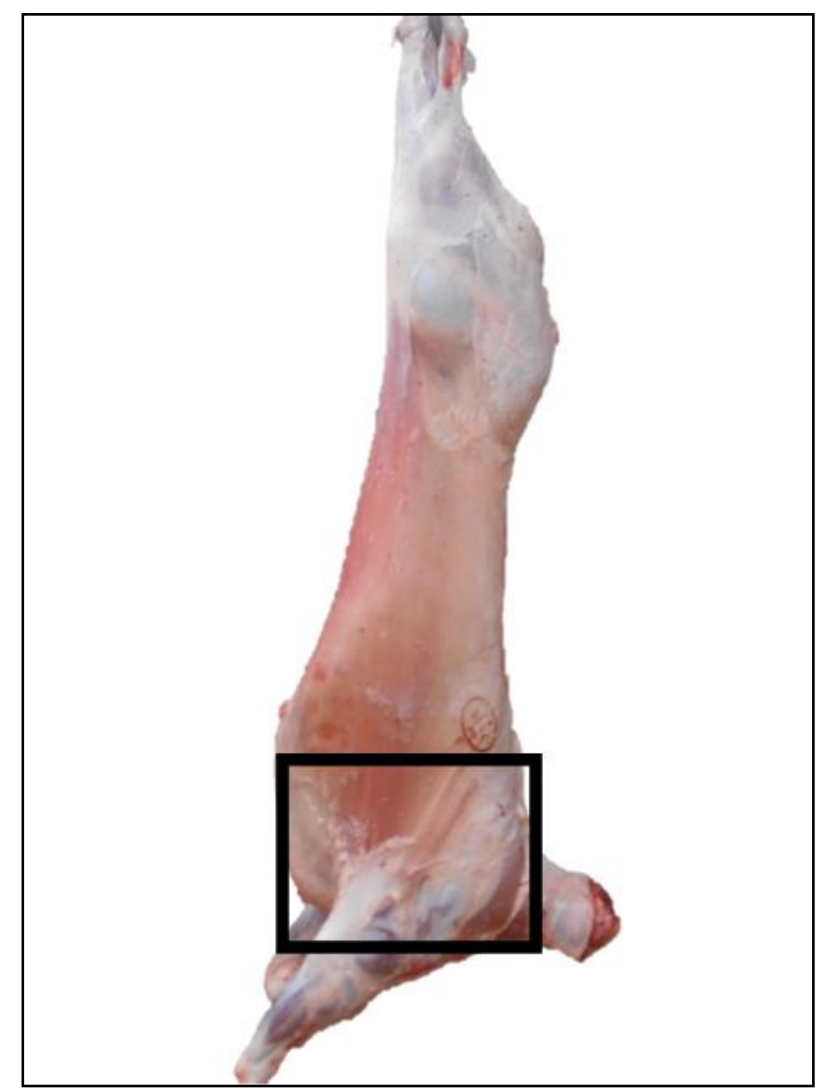

Figure 1 Sampling site on lamb carcass surface.

Table 2 Sheep Cleanliness Categories

\begin{tabular}{ll}
\hline Category 1 & $\begin{array}{l}\text { Clean and Dry - clean with regards to dirt/dung, very minor amounts of loosely } \\
\text { adherent straw/bedding. }\end{array}$ \\
\hline Category 2 & $\begin{array}{l}\text { Slightly Dirty - dry/damp, light contamination with dirt/dung. Small amounts of } \\
\text { loosely adherent straw/bedding. }\end{array}$ \\
\hline Category 3 & $\begin{array}{l}\text { Dirty - dry/damp, significant contamination with dirt/dung. Significant amounts of } \\
\text { loosely adherent straw/bedding. }\end{array}$ \\
\hline Category 4 & $\begin{array}{l}\text { Very Dirty - dry/damp, heavily contaminated with dirt/dung, heavily clagged, } \\
\text { and/or significant amounts of adherent bedding. }\end{array}$ \\
\hline Category 5 & $\begin{array}{l}\text { Filthy and Wet - very wet, very heavily contaminated with dirt/dung, and/or very } \\
\text { heavily clagged, and/or a lot of bedding adherent to the coat. Sheep in this } \\
\text { category will be rejected for slaughter. }\end{array}$ \\
\hline
\end{tabular}

(Source: FSA, 2002)

\subsection{Steam vacuum}

The steam vacuum used in this study was a SV500 (Advance Engineering Ltd., King's Lynn, England), which comprised of a steam and vacuum unit. The steam vacuum equipment was 
fixed on the line and had two hand-held devices equipped with two hoses each, one for steam and another for vacuum. The steam is utilised to sterilise, and to loosen physical contamination from the carcass surface to facilitate removal by the vacuum unit (Hassan et al., 2015).

The steam was produced from potable water, pressure of steam entering the hand-held device was $22 \mathrm{psi}$, and the temperature above $95^{\circ} \mathrm{C}$.

The treatment was carried out by two operatives whilst the carcass was hanging by the forelegs and applied to the forequarter (neck, forelegs, shoulder) and flanks. The application of steam vacuum varied between 3 and 6 seconds and 6 and 9 seconds, at line speeds of 410 and 500 carcasses per hour respectively.

\subsection{Carcass wash}

The carcass wash was constituted by a hose handled by one operative located immediately before chilling. The hose delivered warm $\left(33-37^{\circ} \mathrm{C}\right)$ potable water at a pressure of $145 \mathrm{psi}$. The application of the wash varied between 3 and 6 seconds on different line speeds.

The target area of the wash was the forequarter and used mainly to remove small fine hairs introduced during fleece removal, that are challenging to detect during carcass inspection as the carcass is hung by the hind legs.

\subsection{Microbiological testing}

All samples were collected using a ready-to-use TS/15-B:NaCl (Technical Service Consultants Ltd., Lancashire, UK) carcass sponge contained in an easy to open stomacher pouch dosed with $0.9 \%$ saline.

Swabs were placed back in the sterile stomacher pouch immediately after the sampling collection and sealed. Samples were kept chilled at a temperature of approximately $5^{\circ} \mathrm{C}$ and sent to ALS Laboratories, Shrewsbury, England. The laboratory is accredited for the methods used in bacteriology analyses according to the European standard BS EN ISO/IEC 17025:2005. Analyses of samples were performed no later than 24 hours from sampling collection.

According to Milios et al. (2011) Total viable counts (TVCs) and Enterobacteriaceae should be used as hygiene indicators for lamb carcasses. Therefore, samples were analysed for these microorganisms. Enumeration of TVCs was obtained using plate count agar (PCA, Oxoid) by pour plate technique according to BS EN ISO 4833:1 2013 and incubated at $22 \pm 1^{\circ} \mathrm{C}$ for $72 \pm 3$ 
hours. Enterobacteriaceae counts were obtained by preparing duplicate violet red bile glucose agar (VRBGA, Oxoid) pour plates according to the method of BS ISO 21528-2:2017 and incubated at $37 \pm 1^{\circ} \mathrm{C}$ for $24 \pm 2$ hours.

\subsection{Visual assessment}

Each selected carcass was visually evaluated for contamination by a panel of three trained assessors following the grading system described by Biss and Hathaway (1995), detailed in Table 3. This was conducted and recorded at the same points in the process where microbiological samples were collected.

Table 3 Grading system for visible contamination on lamb carcasses

\begin{tabular}{llll}
\hline Grade & Code & Contaminant & Description \\
\hline & $\mathrm{mW}$ & Wool & $5-10$ strands, or one cluster \\
\cline { 2 - 4 } & $\mathrm{mO}$ & Other $^{1}$ & Maximum diameter $<50 \mathrm{~mm}$ \\
\hline & Wool & $5-10$ minor wool contaminants \\
\cline { 2 - 4 } & $\mathrm{MO}$ & Other & Diameter $50-100 \mathrm{~mm}$ \\
\hline $\mathrm{cI}$ & Ingesta & Maximum diameter $<12 \mathrm{~mm}$ \\
\hline $\mathrm{CF}$ & Faecal Material & Maximum diameter $<12 \mathrm{~mm}$ \\
\cline { 2 - 4 } & $\mathrm{CW}$ & Wool & $>10$ minor contaminants \\
\cline { 2 - 4 } & $\mathrm{CO}$ & Other & Maximum diameter $>100 \mathrm{~mm}$ \\
\cline { 2 - 4 } & $\mathrm{CI}$ & Ingesta & Maximum diameter $>12 \mathrm{~mm}$ \\
\hline $\mathrm{CF}$ & Faecal Material & Maximum diameter $>12 \mathrm{~mm}$ \\
\hline
\end{tabular}

${ }^{1}$ - stains, oil, grease, specks of dust/dirt/sand, rail dust, grass seed.

(Source: Adapted from Biss and Hathaway, 1995 p.778)

\subsection{Colour evaluation}

The colour of carcass surface was measured using a PCE-CSM 1 colorimeter (PCE Instruments UK Ltd., Southampton, UK) under a standard daylight illuminant D65 with a $10^{\circ}$ standard observer according to the CIELab parameters (CIE, 2004). The L* (lightness), a* (redness) and $b^{*}$ (yellowness) colours for each sample were measured four times per carcass, on the same site as shown in Figure 1, and averaged. The colorimeter was calibrated against a standard white porcelain plate prior to sample collection.

The samples were collected on control carcasses, on carcasses after steam vacuum application, and 24 hours after chilling on both control and treatment. 


\subsection{Statistical analysis}

The statistical analyses were conducted using IBM SPSS Statistics version 25 (64-Bit Edition, International Business Machines Corp, New York, USA).

All bacterial counts were converted to logarithmic $\left(\log _{10}\right)$ values. Samples in which Enterobacteriaceae and TVCs were below the minimum detection limit were maintained at minimum detection $-1.763 \log \mathrm{cfu} / \mathrm{cm}^{2}$ (Duffy et al., 2001). This permitted mathematical manipulation of the data with minimal impact on overall results (Byrne et al., 2007).

Descriptive analysis of the data sets performed to provide an overview of their distribution and to test their normality. Correlation between Enterobacteriaceae and TVC was tested through Pearson correlation coefficient (r). Multivariate analysis of variance (MANOVA) was carried out to determine whether there were differences within the different groups (i.e. cleanliness and interventions) and the Enterobacteriaceae and TVC means (Milios et al., 2011). Analyses of variance (ANOVA) was conducted to analyse differences on Enterobacteriaceae and TVC results before and after application of intervention methods (Hochreutener et al., 2017). The level of significance was set at 5\% $(P<0.05)$ in all statistical analyses. All calculations were conducted in the Microsoft Excel 2013 (Microsoft, Redmond, WA, USA).

\section{Results}

\subsection{Microbiological results}

The performance criteria used for the microbiological results was based on Commission Regulation (EC) No 2073/2005. The criteria for Enterobacteriaceae were $\left(\log _{10} \mathrm{cfu} / \mathrm{cm}^{2}\right)$ : satisfactory <0.8, acceptable $0.8-1.8$, and unsatisfactory $>1.8$, and for TVCs were: satisfactory $<2.8$, acceptable $2.8-4.3$, and unsatisfactory $>4.3$.

In general, there was a moderate correlation $(\mathrm{r}=0.39)$ between Enterobacteriaceae and TVC counts which was statistically significant $(P<0.001)$. Enterobacteriaceae was isolated from $57 \%$ of the samples from carcasses before the treatment with intervention methods and from $16 \%$ from the carcasses after 24-hour chilling, whereas TVC was isolated from $96 \%$ and $73 \%$ respectively. 


\subsection{Enterobacteriaceae}

All groups had significantly lower mean loads of Enterobacteriaceae after 24-hour chilling than before chilling $(P<0.001)$ and all results were satisfactory $\left(<0.8 \log \mathrm{cfu} / \mathrm{cm}^{2}\right)$. The steam vacuum was the group with lowest means $\left(-1.76 \log \mathrm{cfu} / \mathrm{cm}^{2}\right)$ of Enterobacteriaceae and the control group with greatest $\left(-1.59 \log \mathrm{cfu} / \mathrm{cm}^{2}\right)$, as shown in Figure 2.

After 24-hour chilling Enterobacteriaceae was detected on $22 \%$ of the samples from control carcasses, $19 \%$ from washed carcasses, $17 \%$ from steam vacuum and washed carcasses, and $5 \%$ from carcasses treated only with steam vacuum.

There was a reduction on Enterobacteriaceae means after treatment for all groups except for the steam vacuum and carcass wash group which increased $0.6 \log \mathrm{cfu} / \mathrm{cm}^{2}$. Nevertheless, all groups achieved between $0.3-0.8 \log \mathrm{cfu} / \mathrm{cm}^{2}$ reduction post chilling. When compared the intervention methods there was a significance $(P<0.05)$ between the control and the steam vacuum groups (Table 6).

Despite the higher means of Enterobacteriaceae on Cat $3 \mathrm{~S}$ before treatment, after intervention the means were the same as Cat $3 \mathrm{U}\left(-1.5 \log \mathrm{cfu} / \mathrm{cm}^{2}\right)$, and after chilling all three groups had the same means $\left(-1.7 \log \mathrm{cfu} / \mathrm{cm}^{2}\right)$. Likewise, statistically there was no significance between the cleanliness groups (Table 4).

On the different line speeds there was no remarkable difference between the means after treatment $\left(-1.4 \log \mathrm{cfu} / \mathrm{cm}^{2}\right)$ and after chilling $\left(-1.7 \log \mathrm{cfu} / \mathrm{cm}^{2}\right)$, and therefore no significance (Table 5).

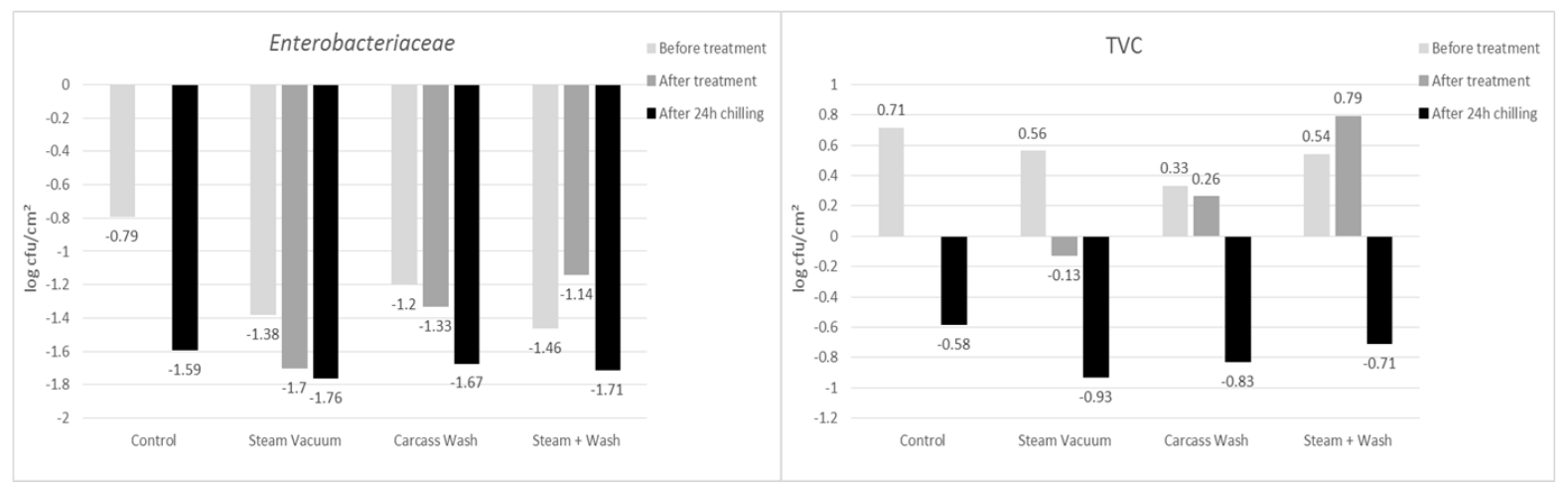

Figure 2 Enterobacteriaceae and TVC mean $\log _{10} \mathrm{cfu} / \mathrm{cm}^{2}$ compared for control, steam vacuum, carcass wash, steam vacuum \& carcass wash before and after treatment, and $24 \mathrm{~h}$ post chilling. 


\subsection{Total viable counts}

The TVC levels were, as expected, higher than the Enterobacteriaceae levels. Nonetheless, a significant $(P<0.001)$ reduction was observed 24-hour post chilling with all results being satisfactory $\left(<2.8 \log \mathrm{cfu} / \mathrm{cm}^{2}\right)$. Generally, all groups had a reduction on TVC means after treatment with exception of steam vacuum \& carcass wash group which increased $1.5 \mathrm{log}$ $\mathrm{cfu} / \mathrm{cm}^{2}$. Despite this, after 24 hours chilling this group had a $1.3 \log \mathrm{cfu} / \mathrm{cm}^{2}$ reduction on TVC means which placed it back within the remain groups (Figure 2).

Similarly to Enterobacteriaceae, the steam vacuum was the group with lowest $(-0.93 \log$ $\left.\mathrm{cfu} / \mathrm{cm}^{2}\right)$ and the control the group $\left(-0.58 \log \mathrm{cfu} / \mathrm{cm}^{2}\right)$ with greatest means of TVC counts. Also, when compared different intervention methods a significance $(P<0.05)$ was observed between these two groups (Table 6).

The Cat $3 \mathrm{U}$ was the group with greatest TVC means $\left(0.9 \log \mathrm{cfu} / \mathrm{cm}^{2}\right)$ before treatment and the Cat 2 the group with greatest reduction $\left(1.3 \log \mathrm{cfu} / \mathrm{cm}^{2}\right)$ post chilling. There was also a significance $(P<0.05)$ between Cat 2 and Cat 3U (Table 4).

Even though, the TVC means on different line speeds were very close before $(0.4$ vs $0.6 \log$ $\left.\mathrm{cfu} / \mathrm{cm}^{2}\right)$ and after treatment $\left(0.4 \mathrm{vs} 0.3 \log \mathrm{cfu} / \mathrm{cm}^{2}\right)$, it was after chilling that the slowest line speed (410) had a greater reduction $\left(1.7 \log \mathrm{cfu} / \mathrm{cm}^{2}\right)$ which was also significant $(P<0.001)$, as shown in Table 5. 
Table 4 Multivariate analysis of variance on the impact of fleece cleanliness on carcass Enterobacteriaceae and TVC means $\left(\log _{10} \mathrm{cfu} / \mathrm{cm}^{2}\right)$

\begin{tabular}{|c|c|c|c|c|c|c|c|}
\hline & \multirow[b]{2}{*}{$\begin{array}{c}\text { (I) } \\
\text { Cleanliness }\end{array}$} & \multirow[b]{2}{*}{$\begin{array}{c}(\mathrm{J}) \\
\text { Cleanliness }\end{array}$} & \multirow{2}{*}{$\begin{array}{c}\text { Mean } \\
\text { Difference } \\
(\mathrm{I}-\mathrm{J})\end{array}$} & \multirow[b]{2}{*}{ SE } & \multirow[b]{2}{*}{ P-Value } & \multicolumn{2}{|c|}{$\begin{array}{l}\text { 95\% Confidence } \\
\text { Interval }\end{array}$} \\
\hline & & & & & & $\begin{array}{l}\text { Lower } \\
\text { Bound }\end{array}$ & $\begin{array}{l}\text { Upper } \\
\text { Bound }\end{array}$ \\
\hline \multirow{6}{*}{ 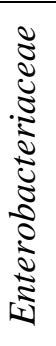 } & \multirow{2}{*}{ Cat 2} & Cat $3 \mathrm{~S}$ & -0.021 & 0.045 & 0.891 & -0.127 & 0.086 \\
\hline & & Cat $3 \mathrm{U}$ & -0.009 & 0.045 & 0.981 & -0.115 & 0.098 \\
\hline & \multirow[t]{2}{*}{ Cat $3 S^{a}$} & Cat 2 & 0.021 & 0.045 & 0.891 & -0.086 & 0.127 \\
\hline & & Cat $3 \mathrm{U}$ & 0.012 & 0.045 & 0.961 & -0.095 & 0.119 \\
\hline & \multirow[t]{2}{*}{ Cat $3 \mathrm{U}^{\mathrm{a}}$} & Cat 2 & 0.009 & 0.045 & 0.981 & -0.098 & 0.115 \\
\hline & & Cat $3 \mathrm{~S}$ & -0.012 & 0.045 & 0.961 & -0.119 & 0.095 \\
\hline \multirow{6}{*}{$\begin{array}{l}U \\
Z\end{array}$} & \multirow[t]{2}{*}{ Cat 2} & Cat $3 \mathrm{~S}$ & -0.117 & 0.104 & 0.498 & -0.362 & 0.128 \\
\hline & & Cat $3 \mathrm{U}$ & -.2704 & 0.104 & $0.027^{\mathrm{c}}$ & -0.515 & -0.025 \\
\hline & \multirow[t]{2}{*}{ Cat $3 \mathrm{~S}$} & Cat 2 & 0.117 & 0.104 & 0.498 & -0.128 & 0.362 \\
\hline & & Cat $3 \mathrm{U}$ & -0.153 & 0.104 & 0.307 & -0.399 & 0.093 \\
\hline & \multirow[t]{2}{*}{ Cat $3 \mathrm{U}$} & Cat 2 & .2704 & 0.104 & $0.027^{\mathrm{c}}$ & 0.025 & 0.515 \\
\hline & & Cat $3 \mathrm{~S}$ & 0.153 & 0.104 & 0.307 & -0.093 & 0.399 \\
\hline
\end{tabular}

(SE) Standard Error

a - shorn

$\mathrm{b}-$ unshorn

$c-$ significant at $\mathrm{p}<0.05$

Table 5 Statistics on the influence of slaughter line speed on carcass Enterobacteriaceae and TVC means $\left(\log _{10} \mathrm{cfu} / \mathrm{cm}^{2}\right)$

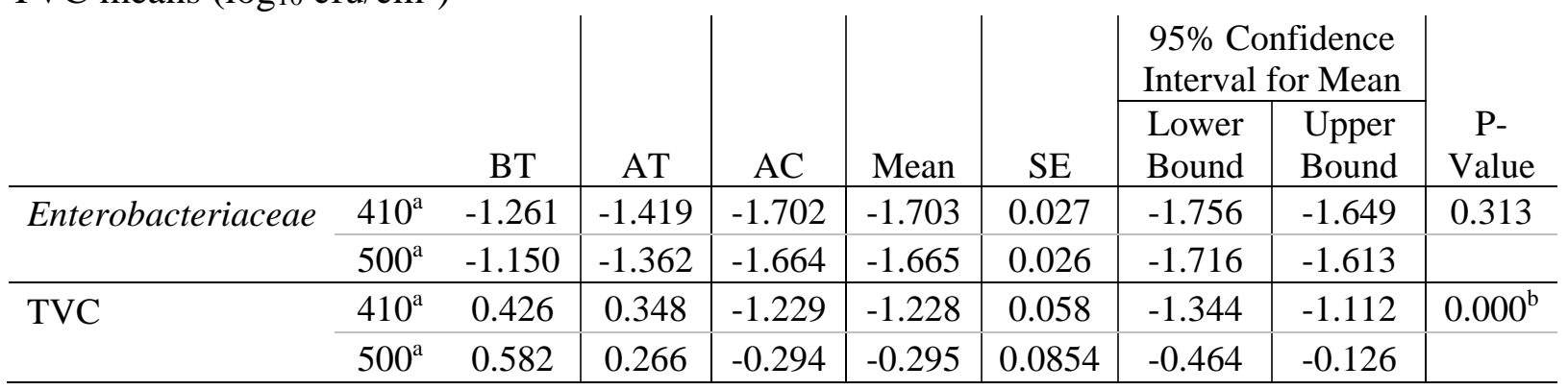

(BT) Mean before treatment

(AT) Mean after treatment

(AC) Mean after $24 \mathrm{~h}$ chilling

(SE) Standard Error

$a-$ number of carcasses per hour

$\mathrm{b}-$ significant at $\mathrm{p}<0.05$ 
Table 6 Multivariate analysis of variance on the impact of different intervention methods on carcass Enterobacteriaceae and TVC means $\left(\log _{10} \mathrm{cfu} / \mathrm{cm}^{2}\right)$

\begin{tabular}{|c|c|c|c|c|c|c|c|}
\hline \multirow{2}{*}{\multicolumn{2}{|c|}{$\begin{array}{l}\text { (I) Intervention } \\
\text { method }\end{array}$}} & \multirow[b]{2}{*}{$\begin{array}{l}\text { (J) Intervention } \\
\text { method }\end{array}$} & \multirow{2}{*}{$\begin{array}{l}\text { Mean } \\
\text { Differenc } \\
\text { e (I-J) }\end{array}$} & \multirow[b]{2}{*}{ SE } & \multirow[b]{2}{*}{ P-Value } & \multicolumn{2}{|c|}{$95 \%$ Confidence Interval } \\
\hline & & & & & & $\begin{array}{l}\text { Lower } \\
\text { Bound }\end{array}$ & $\begin{array}{l}\text { Upper } \\
\text { Bound }\end{array}$ \\
\hline \multirow{12}{*}{ 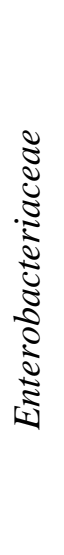 } & Control & Carcass Wash & 0.0695 & 0.05205 & 0.541 & -0.0653 & 0.2044 \\
\hline & & Steam + Wash & 0.1121 & 0.05319 & 0.154 & -0.0257 & 0.2498 \\
\hline & & Steam Vacuum & .1622 & 0.05205 & $0.011^{\mathrm{a}}$ & 0.0274 & 0.2970 \\
\hline & Steam & Carcass Wash & -0.0927 & 0.05138 & 0.275 & -0.2257 & 0.0404 \\
\hline & Vacuum & Control & -.1622 & 0.05205 & $0.011^{\mathrm{a}}$ & -0.2970 & -0.0274 \\
\hline & & Steam + Wash & -0.0501 & 0.05254 & 0.776 & -0.1862 & 0.0859 \\
\hline & Carcass & Control & -0.0695 & 0.05205 & 0.541 & -0.2044 & 0.0653 \\
\hline & Wash & Steam + Wash & 0.0425 & 0.05254 & 0.850 & -0.0935 & 0.1786 \\
\hline & & Steam Vacuum & 0.0927 & 0.05138 & 0.275 & -0.0404 & 0.2257 \\
\hline & Steam + & Carcass Wash & -0.0425 & 0.05254 & 0.850 & -0.1786 & 0.0935 \\
\hline & Wash & Control & -0.1121 & 0.05319 & 0.154 & -0.2498 & 0.0257 \\
\hline & & Steam Vacuum & 0.0501 & 0.05254 & 0.776 & -0.0859 & 0.1862 \\
\hline \multirow{12}{*}{ U } & Control & Carcass Wash & 0.2174 & 0.11949 & 0.267 & -0.0921 & 0.5269 \\
\hline & & Steam + Wash & 0.0860 & 0.12211 & 0.895 & -0.2303 & 0.4022 \\
\hline & & Steam Vacuum & .3381 & 0.11949 & $0.026^{\mathrm{a}}$ & 0.0286 & 0.6476 \\
\hline & Steam & Carcass Wash & -0.1207 & 0.11795 & 0.736 & -0.4262 & 0.1848 \\
\hline & Vacuum & Control & -.3381 & 0.11949 & $0.026^{\mathrm{a}}$ & -0.6476 & -0.0286 \\
\hline & & Steam + Wash & -0.2521 & 0.12060 & 0.160 & -0.5645 & 0.0602 \\
\hline & Carcass & Control & -0.2174 & 0.11949 & 0.267 & -0.5269 & 0.0921 \\
\hline & Wash & Steam + Wash & -0.1314 & 0.12060 & 0.696 & -0.4438 & 0.1809 \\
\hline & & Steam Vacuum & 0.1207 & 0.11795 & 0.736 & -0.1848 & 0.4262 \\
\hline & Steam + & Carcass Wash & 0.1314 & 0.12060 & 0.696 & -0.1809 & 0.4438 \\
\hline & Wash & Control & -0.0860 & 0.12211 & 0.895 & -0.4022 & 0.2303 \\
\hline & & Steam Vacuum & 0.2521 & 0.12060 & 0.160 & -0.0602 & 0.5645 \\
\hline
\end{tabular}

(SE) Standard Error

$\mathrm{a}-$ significant at $\mathrm{p}<0.05$

\subsection{Visual assessment}

Examination of results revealed that before treatment the majority of carcasses were visibly contaminated with wool, affecting 54\% (Table 7 and 8) of the carcasses in which $65 \%$ were "critical" wool contamination. The "critical" wool occurred predominantly on Cat 3U. In contrast, "minor" wool contamination occurred more frequently on Cat 2 and Cat 3S groups. The reduction on wool contamination levels resulted from both steam vacuum and carcass wash treatments was $80 \%$.

"Other" contamination comprised mainly rail dust except one case of rail grease. No pattern emerged for "other" contamination, however minor "other" was the predominant. Nevertheless, both treatments have reduced $100 \%$ "other" contamination from the carcass surfaces. There were four cases of ingesta contamination which were also effectively 
removed by the steam vacuum treatment. Faecal was not observed in any carcass on this study.

When compared the impact of different line speeds (410 vs 500) on overall contamination levels there were no significant difference $(P>0.05)$. The most significant trend observed was higher levels of wool contamination on carcasses derived from Cat $3 \mathrm{U}$ group than Cat 2 or Cat $3 \mathrm{~S}$ groups, which was also statistically significant $(P<0.05)$.

Table 7 Visible contamination before and after steam vacuum treatment

\begin{tabular}{|c|c|c|c|c|c|c|c|c|c|c|c|c|c|c|c|c|}
\hline \multirow[t]{2}{*}{$\begin{array}{l}\text { Line } \\
\text { speed }\end{array}$} & \multirow[t]{2}{*}{$\begin{array}{c}\text { Cleanliness } \\
\text { category }\end{array}$} & \multirow[t]{2}{*}{$\mathrm{N}$} & \multicolumn{6}{|c|}{$\begin{array}{l}\text { Contamination before } \\
\text { steam vacuum } \\
\text { treatment }\end{array}$} & & \multicolumn{7}{|c|}{$\begin{array}{c}\text { Contamination after } \\
\text { steam vacuum } \\
\text { treatment }\end{array}$} \\
\hline & & & $\mathrm{mW}$ & MW & $\mathrm{CW}$ & $\mathrm{mO}$ & MO & $\mathrm{CO}$ & cI & $\mathrm{mW}$ & MW & $\mathrm{CW}$ & $\mathrm{mO}$ & $\mathrm{MO}$ & $\mathrm{CO}$ & $\mathrm{cI}$ \\
\hline 410 & Cat 2 & 10 & 3 & 0 & 0 & 1 & 0 & 0 & 0 & 0 & 0 & 0 & 0 & 0 & 0 & 0 \\
\hline 500 & Cat 2 & 10 & 0 & 1 & 1 & 1 & 1 & 0 & 2 & 0 & 0 & 0 & 0 & 0 & 0 & 0 \\
\hline 410 & Cat $3 S^{b}$ & 10 & 2 & 1 & 0 & 0 & 1 & 0 & 0 & 0 & 0 & 0 & 0 & 0 & 0 & 0 \\
\hline 500 & Cat $3 \mathrm{~S}$ & 10 & 0 & 0 & 7 & 1 & 0 & 1 & 2 & 1 & 0 & 0 & 0 & 0 & 0 & 0 \\
\hline 410 & Cat $3 \mathrm{U}^{\mathrm{b}}$ & 10 & 2 & 0 & 8 & 1 & 0 & 0 & 0 & 2 & 0 & 0 & 0 & 0 & 0 & 0 \\
\hline 500 & Cat $3 \mathrm{U}$ & 10 & 0 & 0 & 10 & 1 & 0 & 0 & 0 & 4 & 0 & 0 & 0 & 0 & 0 & 0 \\
\hline
\end{tabular}

Table 8 Visible contamination before and after carcass wash treatment

\begin{tabular}{|c|c|c|c|c|c|c|c|c|c|c|c|c|c|c|c|c|}
\hline \multirow[t]{2}{*}{$\begin{array}{l}\text { Line } \\
\text { speed }\end{array}$} & \multirow[t]{2}{*}{$\begin{array}{c}\text { Cleanliness } \\
\text { category }\end{array}$} & \multirow[t]{2}{*}{$\mathrm{N}$} & \multicolumn{6}{|c|}{$\begin{array}{c}\text { Contamination before } \\
\text { carcass wash } \\
\text { treatment }\end{array}$} & & \multicolumn{7}{|c|}{$\begin{array}{c}\text { Contamination after } \\
\text { carcass wash } \\
\text { treatment }\end{array}$} \\
\hline & & & $\mathrm{mW}$ & MW & $\mathrm{CW}$ & $\mathrm{mO}$ & MO & $\mathrm{CO}$ & $\mathrm{cI}$ & $\mathrm{mW}$ & MW & $\mathrm{CW}$ & $\mathrm{mO}$ & MO & $\mathrm{CO}$ & cI \\
\hline 410 & Cat 2 & 10 & 1 & 0 & 0 & 1 & 0 & 0 & 0 & 0 & 0 & 0 & 0 & 0 & 0 & 0 \\
\hline 500 & Cat 2 & 10 & 2 & 2 & 0 & 0 & 0 & 0 & 0 & 0 & 0 & 0 & 0 & 0 & 0 & 0 \\
\hline 410 & Cat $3 S^{b}$ & 10 & 3 & 2 & 0 & 1 & 0 & 0 & 0 & 0 & 0 & 0 & 0 & 0 & 0 & 0 \\
\hline 500 & Cat $3 \mathrm{~S}$ & 10 & 1 & 0 & 0 & 0 & 0 & 0 & 0 & 0 & 0 & 0 & 0 & 0 & 0 & 0 \\
\hline 410 & Cat $3 \mathrm{U}^{\mathrm{b}}$ & 10 & 1 & 2 & 6 & 1 & 0 & 0 & 0 & 2 & 0 & 0 & 0 & 0 & 0 & 0 \\
\hline 500 & Cat 3U & 10 & 0 & 0 & 10 & 1 & 0 & 0 & 0 & 2 & 0 & 0 & 0 & 0 & 0 & 0 \\
\hline
\end{tabular}




\subsection{Colour results}

In the present study, there were no significant differences $(P>0.05)$ on the carcass lightness ( $\mathrm{L}^{*}$ value), redness ( $\mathrm{a}^{*}$ value), and yellowness ( $\mathrm{b}^{*}$ value) between the control group and the steam vacuum group, as shown in Table 9.

Table 9 Means and standard errors (SE) for carcass colour characteristics between control and steam vacuum

\begin{tabular}{|c|c|c|c|c|c|}
\hline & \multicolumn{2}{|c|}{ Control } & \multicolumn{2}{|c|}{ Steam vacuum } & \multirow{2}{*}{ P-Value } \\
\hline & Mean & SE & Mean & SE & \\
\hline \multicolumn{6}{|c|}{ Colour parameters at Oh } \\
\hline $\mathrm{L}$ & 60.84 & 1.81 & 62.15 & 1.35 & 0.569 \\
\hline $\mathrm{a}$ & 8.69 & 0.90 & 8.85 & 0.83 & 0.896 \\
\hline $\mathrm{b}$ & 7.72 & 0.79 & 8.36 & 0.76 & 0.570 \\
\hline \multicolumn{6}{|c|}{ Colour parameters at $24 \mathrm{~h}$} \\
\hline $\mathrm{L}$ & 57.44 & 1.68 & 57.51 & 1.76 & 0.977 \\
\hline $\mathrm{a}$ & 13.56 & 0.80 & 15.61 & 1.66 & 0.280 \\
\hline $\mathrm{b}$ & 9.64 & 0.32 & 9.96 & 0.42 & 0.548 \\
\hline
\end{tabular}

\section{Discussion}

\subsection{Microbiological results}

The moderate correlation ( $\mathrm{r}=0.39)$ between Enterobacteriaceae and TVC was also observed in another lamb study (Milios et al., 2011), and in a beef carcass study a weak correlation between a subgroup of Enterobacteriaceae (Escherichia coli) and aerobic plate count (APC) was also established (Gill et al., 1996). Both studies (Gill et al., 1996; Milios et al., 2011) advocated that the evaluation of the hygiene of process should be based on enumeration of both Enterobacteriaceae and TVC, or solely Enterobacteriaceae. When only TVC enumeration is considered, erroneous conclusions could be drawn regarding the hygiene of the slaughter line process. Enterobacteriaceae and Escherichia coli (E. coli) are accepted indicators of faecal contamination, whereas TVC provide information concerning the shelf life (ICMSF, 2000). 


\subsection{Fleece cleanliness}

In this study, there was a trend for lambs from Cat $3 \mathrm{U}$ cleanliness status to result in carcasses with the greatest levels of TVC. However, the carcasses from this group also yielded the lowest levels of Enterobacteriaceae before treatment, in contrast with its counterpart Cat $3 \mathrm{~S}$ which had the greatest initial levels.

Similarly, Hauge et al. (2011) study has revealed that carcasses resulted from lambs shorn in the abattoir before slaughter had a significant reduction in APC levels, but no significant reduction on E. coli. Also, it was noted that E. coli levels on carcasses from lambs shorn in the abattoir immediately before slaughter were high when compared with those shorn on farm. Omer et al. (2015) research has also reported carcasses produced from unshorn sheep and lambs with significant higher APC levels than the ones produced from shorn sheep and lambs, but in contrast to the present study the levels of Enterobacteriaceae and E. coli were equally high.

The increase of Enterobacteriaceae and E. coli levels on carcasses from lambs sheared immediately before slaughter may be a result of faecal cross-contamination via shearing equipment and/or operatives hands.

Biss and Hathaway, (1996b) have reported that shearing lambs at specific sites reduced carcass contamination, whereas Roberts (1980) has found no significant difference.

Carcasses derived from the Cat $3 \mathrm{U}$ group have also shown the greatest levels of wool contamination. Nevertheless, the use of parameters such as visible contamination to measure carcass hygiene must be treated with caution as there has not always been an observed correlation between visible and microbiological contamination (Biss and Hathaway, 1996; Gill et al., 1996).

Faecal contamination was not observed in this study, this may be due to the steam vacuum equipment being positioned before evisceration and the carcass wash being positioned after the post-mortem inspection.

\subsection{Line speed}

When compared both slaughter line speeds there was no significance $(P=0.313)$ on Enterobacteriaceae means but there was strong significance $(P<0.001)$ on TVC means. A further examination found that the different line speeds were significant $(P<0.05)$ on TVC reduction when using steam vacuum equipment. The reason is that the slower the line speed the more time the slaughter operative has to apply the treatment, hence resulting in greatest 
microbial reduction. Hochreutener et al. (2017) stressed that the exposure time is an important factor for the antimicrobial effect of the steam vacuum.

Research has suggested that slaughter line speed may have a high impact on carcass contamination (Roberts, 1980). A study conducted on three different line speeds reported that the levels of APC increased with the line speed (Bell, 1997), which has been supported by this study. In contrast, another study found lower levels of APC at higher speed lines (Hogue et al., 1993). Nevertheless, the authors noted that the higher speed line plants in comparison with lower speed had advantages such as established quality control programmes designed to identify and prevent sources of contamination in the slaughter line and specialised labour, which may explain the study outcome. Sheridan (1998) concluded that the correlation between line speed and carcass contamination is not linear and is influenced by several factors such as operatives' fatigue, knife skills, the number of hours worked, and implementation of food safety management systems (HACCP). The most important factor highlighted is whether or not the operatives have sufficient time to carry out their tasks under good hygienic practices. This might be the reason for reduced levels of TVC on the lower speed line, since the same number of operatives have had extra time to carry out their tasks.

\subsection{Steam vacuum}

The application of steam vacuum has resulted in the highest microbial load reduction after both treatment and chilling (Figure 2). The reduction on Enterobacteriaceae mean values after treatment were $0.3 \log \mathrm{cfu} / \mathrm{cm}^{2}(P<0.001)$ and TVC were to $0.7 \log \mathrm{cfu} / \mathrm{cm}^{2}(P<0.001)$. Furthermore, the Enterobacteriaceae means on Cat $3 \mathrm{~S}$ and Cat $3 \mathrm{U}$ were reduced to the same levels as Cat 2.

According to Gill and Landers (2003), the microbial effects of a decontamination treatment must be considered trivial when the results before and after treatment do not differ by at least $0.5 \log$ unit. However, the initial levels of contamination were relatively low for both Enterobacteriaceae $\left(-1.38 \log \mathrm{cfu} / \mathrm{cm}^{2}\right)$ and TVC $\left(0.56 \log \mathrm{cfu} / \mathrm{cm}^{2}\right)$ when compared to other studies conducted on the effectiveness of a steam vacuum on lamb and sheep carcasses (Milios et al., 2011; Hassan et al., 2015; Omer et al., 2015).

Milios et al. (2011) have observed a reduction of almost $1.0 \log \mathrm{cfu} / \mathrm{cm}^{-2}(P<0.001)$ in Enterobacteriaceae counts and a reduction of $0.7 \mathrm{log} \mathrm{cfu} / \mathrm{cm}^{-2}(P<0.001)$ on TVC after steam vacuum application on lamb carcasses. Hassan et al. (2015) have researched the effect of steam vacuum on lamb and sheep carcasses and reported a reduction on Enterobacteriaceae 
of $1.25 \log \mathrm{cfu} / \mathrm{cm}^{-2}(P<0.001)$ and on total plate count (TPC) $0.65 \log \mathrm{cfu} / \mathrm{cm}^{-2}(P<0.001)$. Omer et al. (2015) have also outlined a reduction on Enterobacteriaceae, E. coli., and APC on carcasses treated with steam vacuum. Despite the positive effect on microbial decontamination using steam vacuum reported in these studies (Milios et al., 2011; Hassan et al., 2015; Omer et al., 2015), it is important to highlight that the exposure times, sampled sites, and initial levels of contamination are different from this study, and therefore a direct comparison cannot be obtained.

Milios et al. (2011) have also evaluated the impact of steam vacuum on organoleptic characteristics of lamb carcasses and found no adverse effect on colour, odour, and overall acceptability, which is congruent with colour results obtained in this study.

Steam vacuum spot decontamination, as used in this study, strongly depends on the operative skills to identify and perform a correct application of the equipment on the areas of the carcass which are most prone to contamination during slaughter process (Hassan et al., 2015). However, Gill (2009) reported that the effectiveness of steam vacuum on microbiological reduction will only occur when the microbial conditions of carcasses are associated with visible contamination, as sites that are not visibly contaminated may carry large numbers of bacteria.

\subsection{Carcass wash}

Carcass wash has shown a consistent reduction on both Enterobacteriaceae and TVC means. After the treatment application the carcass wash group performed better on Enterobacteriaceae levels than the steam vacuum \& carcass wash group, and after chilling the carcass wash group performed better on TVC levels than both control and steam vacuum \& carcass wash groups (Figure 2).

The means $\log$ reduction after treatment on Enterobacteriaceae were $-0.13 \log \mathrm{cfu} / \mathrm{cm}^{2}$ $(\mathrm{p}=0.305)$ and on TVC were $0.07 \log \mathrm{cfu} / \mathrm{cm}^{2}(\mathrm{p}=0.759)$. The initial contamination levels were also low, $-1.2 \log \mathrm{cfu} / \mathrm{cm}^{2}$ and $0.33 \log \mathrm{cfu} / \mathrm{cm}^{2}$ respectively, but in this case the difference was not significant.

A study conducted on beef and lamb carcass washed with water at ambient temperature $\left(15.6^{\circ} \mathrm{C}\right.$ ) has shown a reduction on APC 0.8-2.2 log $\mathrm{cfu} / \mathrm{cm}^{2}$ (Dorsa et al., 1996). Another study conducted on carcass wash $\left(40-55^{\circ} \mathrm{C}\right)$ reported that washing beef carcasses was effective when the initial number of aerobes were relatively high, but ineffective when the numbers were relatively low (Gill and Landers, 2003). 
In contrast, Gill et al. (1996) advocated that washing beef carcasses with water at $40^{\circ} \mathrm{C}$ had a reduction on microbial contamination insufficient to enhance its safety. Another study on beef carcasses washed with cold water for 5 seconds reported no significant decline on APC levels after wash and some sites (flank and brisket) observed an increase of $0.7 \log \mathrm{cfu} / \mathrm{cm}^{2}$ and $1.2 \log \mathrm{cfu} / \mathrm{cm}^{2}$, respectively (Bell, 1997). A more recent study on sheep carcasses reported an increase on aerobic colony count $\left(0.85-0.97 \log \mathrm{cfu} / \mathrm{cm}^{2}\right)$ and Enterobacteriaceae $\left(1.16-2.51 \log \mathrm{cfu} / \mathrm{cm}^{2}\right)$ after chilling, especially on the shoulder area (Telli, 2018). Prasai et al. (1995) found that washing can spread microbial contamination from one area of the carcass to another. In other study there was observed a reduction only in a specific carcass site (Jericho et al., 1995).

In the present study, only the forequarter area was evaluated and therefore it cannot be concluded whether or not contamination has been redistributed to adjacent areas or that carcass wash is effective when applied to the whole carcass rather than this specific area. Nevertheless, the carcass wash has also shown potential in the reduction of visible contamination, as shown in Table 8. Bolton et al. (2001) stressed that washing carcasses with cold $\left(10-15^{\circ} \mathrm{C}\right)$ and warm $\left(15-40^{\circ} \mathrm{C}\right)$ water is not considered to be a decontamination step during slaughter as its effects are related solely to improve carcass appearance and not food safety.

\subsection{Steam vacuum and carcass wash}

The combination of steam vacuum and carcass wash had no improvement on microbial decontamination when compared with interventions individually. In fact there was an increase on microbial load for both Enterobacteriaceae and TVC immediately after treatment, which was not observed on steam vacuum or carcass wash alone. This might be due to re-contamination post treatment by the equipment or operatives. Another explanation could be that microorganisms were present at higher concentrations on the side of the carcass swabbed after the application of treatment than the side swabbed before.

\section{Conclusion}

In this study, the steam vacuum has demonstrated to be effective under commercial conditions in reducing microbiological and visible contamination. Even though carcass wash has not shown to reduce significantly microbial contamination, it has improved the carcass 
appearance. Further investigation shall be conducted to determine whether the water spreads contamination to other areas on the carcass.

The line speed has shown to be a contributor to reduce carcass contamination. Nevertheless, when setting the line to operate at an optimum speed different factors must be considered such as operatives skills and working hours. This will ensure that operatives have time to carry out their tasks to the best hygiene standard.

Shearing Cat3 animals immediately before slaughter has shown to increase Enterobacteriaceae levels, therefore it may be justifiable to sterilise the shearing equipment to prevent cross-contamination, as not shearing increases wool contamination on carcass.

Despite of the effectiveness of interventions methods on carcass decontamination, these must always be seen as an integrated part of the food safety management system (HACCP) to enhance food safety, and not a replacement to good hygienic practices. 


\section{References}

Bacon, R.T., Sofos, J.N., Belk, K.E. and Smith, G.C., (2002). Application of a commercial steam vacuum unit to reduce inoculated Salmonella on chilled fresh beef adipose tissue. Dairy Food and Environmental Sanitation, 22(3), pp.184-190.

Behravesh, C.B., Williams, I.T. and Tauxe, R.V., (2012). Emerging foodborne pathogens and problems: expanding prevention efforts before slaughter or harvest. In Improving food safety through a one health approach: workshop summary. National Academies Press (US).

Bell, R.G., (1997). Distribution and sources of microbial contamination on beef carcasses. Journal of Applied Microbiology, 82(3), pp.292-300.

Biss, M.E. and Hathaway, S.C., (1995). Microbiological and visible contamination of lamb carcasses according to pre-slaughter presentation status: implications for HACCP. Journal of Food Protection, 58(7), pp.776-783.

Biss, M.E. and Hathaway, S.C., (1996). The effect of different on-line dressing practices on microbiological and visible contamination of lamb carcasses. New Zealand veterinary journal, 44(2), pp.55-60.

Bolton, D.J., Doherty, A.M. and Sheridan, J.J., (2001). Beef HACCP: intervention and nonintervention systems. International Journal of Food Microbiology, 66(1-2), pp.119-129.

Byrne, B., Dunne, G., Lyng, J. and Bolton, D.J., (2007). The development of a 'clean sheep policy' in compliance with the new Hygiene Regulation (EC) 853/2004 (Hygiene 2). Food microbiology, 24(3), pp.301-304.

CIE (Commission Internationale de L'éclairage). (2004). CIE 15:2004 Colorimetry. (3 ${ }^{\text {rd }}$ ed.). Commission Internationale de l'Eclairage, Vienna.

Commission Regulation (EC) No 2073/2005 of 5 November 2005 on microbiological criteria for foodstuffs. [On-line]. Official Journal of the European Union L 338/1. Available from: https://eur-lex.europa.eu/eli/reg/2005/2073/oj [Accessed 06 July 2019].

Dickson, J.S. and Acuff, G.R., (2017). Maintaining the safety and quality of beef carcass meat. In Ensuring safety and quality in production of beef, 1, pp.145-167

Dorsa, W.J., Cutter, C.N. and Siragusa, G.R., (1996). Effectiveness of a steam-vacuum sanitizer for reducing Escherichia coli O157: H7 inoculated to beef carcass surface tissue. Letters in applied microbiology, 23(1), pp.61-63.

Duffy, E.A., Belk, K.E., Sofos, J.N., LeValley, S.B., Kain, M.L., Tatum, J.D., Smith, G.C. and Kimberling, C.V., (2001). Microbial contamination occurring on lamb carcasses processed in the United States. Journal of Food Protection, 64(4), pp.503-508.

Fisher, A., Wilkin, C.A. and Purnell, G., (2007). The production and microbiological status of skin-on sheep carcasses. Meat science, 77(4), pp.467-473.

FSA (Food Standards Agency). (2002). Red Meat Safety \& Clean Livestock [On-line]. Gov.Scot. Available from:

https://www.foodstandards.gov.scot/downloads/Red_meat_safety_and_clean_livestock.pdf [Accessed 06 April 2019]. 
FSA (Food Standards Agency). (2007). Clean sheep for slaughter. A guide for producers [On-line]. Gov.GG. Available from:

https://www.gov.gg/CHttpHandler.ashx?id=107804\&p=0 [Accessed 06 April 2019].

Gill, C.O., (2009). Effects on the microbiological condition of product of decontaminating treatments routinely applied to carcasses at beef packing plants. Journal of food protection, 72(8), pp.1790-1801.

Gill, C.O., Badoni, M. and Jones, T., (1996). Hygienic effects of trimming and washing operations in a beef-carcass-dressing process. Journal of Food Protection, 59(6), pp.666-669.

Gill, C.O. and Landers, C., (2003). Microbiological effects of carcass decontaminating treatments at four beef packing plants. Meat Science, 65(3), pp.1005-1011.

Godfray, H.C.J., Aveyard, P., Garnett, T., Hall, J.W., Key, T.J., Lorimer, J., Pierrehumbert, R.T., Scarborough, P., Springmann, M. and Jebb, S.A., (2018). Meat consumption, health, and the environment. Science, 361(6399), p.eaam5324.

Hassan, A.A., Skjerve, E., Bergh, C. and Nesbakken, T., (2015). Microbial effect of steam vacuum pasteurisation implemented after slaughtering and dressing of sheep and lamb. Meat science, 99, pp.32-37.

Hauge, S.J., Nafstad, O., Skjerve, E., Røtterud, O.J. and Nesbakken, T., (2011). Effects of shearing and fleece cleanliness on microbiological contamination of lamb carcasses. International journal of food microbiology, 150(2-3), pp.178-183.

Hochreutener, M., Zweifel, C., Corti, S. and Stephan, R., (2017). Effect of a commercial steam-vacuuming treatment implemented after slaughtering for the decontamination of cattle carcasses. Italian journal of food safety, 6(3).

Hogue, A.T., Dreesen, D.W., Green, S.S., Ragland, R.D., James, W.O., Bergeron, E.A., Cook, L.V., Pratt, M.D. and Martin, D.R., (1993). Bacteria on beef briskets and ground beef: correlation with slaughter volume and ante-mortem condemnation. Journal of food protection, 56(2), pp.110-113.

Huffman, R.D., (2002). Current and future technologies for the decontamination of carcasses and fresh meat. Meat Science, 62(3), pp.285-294.

Hugas, M. and Tsigarida, E., (2008). Pros and cons of carcass decontamination: the role of the European Food Safety Authority. Meat Science, 78(1-2), pp.43-52.

ICMSF (International Commission on Microbiological Specifications for Foods). (2000). Microorganisms in Foods 6: Microbial ecology of food commodities. Maryland: Aspen Publishers, Inc.

ISO (International Organisation for Standardisation). (2015). ISO 17604:2015: Microbiology of the food chain - carcass sampling for microbiological analysis. Geneva: ISO.

Jericho, K.W., Bradley, J.A. and Kozub, G.C., (1995). Microbiological evaluation of carcasses before and after washing in a beef slaughter plant. Journal of the American Veterinary Medical Association, 206(4), pp.452-455.

Kochevar, S.L., Sofos, J.N., Bolin, R.R., Reagan, J.O. and Smith, G.C., (1997). Steam vacuuming as a pre-evisceration intervention to decontaminate beef carcasses. Journal of Food Protection, 60(2), pp.107-113. 
Milios, K., Mataragas, M., Pantouvakis, A., Drosinos, E.H. and Zoiopoulos, P.E., (2011). Evaluation of control over the microbiological contamination of carcasses in a lamb carcass dressing process operated with or without pasteurizing treatment. International journal of food microbiology, 146(2), pp.170-175.

Milios, K.T., Drosinos, E.H. and Zoiopoulos, P.E., (2014). Food Safety Management System validation and verification in meat industry: Carcass sampling methods for microbiological hygiene criteria-A review. Food Control, 43, pp.74-81.

Milios, K., Drosinos, E.H. and Zoiopoulos, P.E., (2017). Carcass decontamination methods in slaughterhouses: a review. Journal of the Hellenic Veterinary Medical Society, 65(2), pp.6578.

Omer, M.K., Hauge, S.J., Østensvik, Ø., Moen, B., Alvseike, O., Røtterud, O.J., Prieto, M., Dommersnes, S., Nesteng, O.H. and Nesbakken, T., (2015). Effects of hygienic treatments during slaughtering on microbial dynamics and contamination of sheep meat. International journal of food microbiology, 194, pp.7-14.

Prasai, R.K., Phebus, R.K., Garcia Zepeda, C.M., Kastner, C.L., Boyle, A.E. and Fung, D.Y.C., (1995). Effectiveness of trimming and/or washing on microbiological quality of beef carcasses. Journal of Food Protection, 58(10), pp.1114-1117.

Roberts, T.A., (1980). Contamination of meat: the effects of slaughter practices on the bacteriology of the red meat carcass. Royal Society of Health Journal, 100(1), pp.3-9.

Sheridan, J.J., (1998). Sources of contamination during slaughter and measures for control. Journal of Food Safety, 18(4), pp.321-339.

Telli, A., (2018). Determination of microbial contamination, $\mathrm{pH}$ and temperature changes in sheep and cattle carcasses during the slaughter and pre-cooling processes in Konya, Turkey. Italian Journal of Food Science, 30(4), pp.828-839. 